\title{
Obituaries
}

Obituaries should be submitted by email to Jadene Doak at jadene.doak@springernature.com

All submitted obituaries should be 400 words maximum in length (apart from obituaries for past presidents of the BDA where the length should be 800 words).

Content of the obituary is down to the individual author, and the approval of the family should be given for the obituary prior to submission to the BDJ.

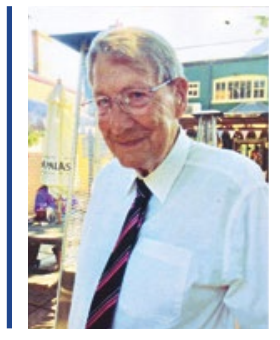

James Hubert

Baines

1932-2019

Jim Baines was born in Reading; his father was a dentist, working in the schools' service. The family moved firstly to Yorkshire, and then to Dereham in Norfolk. Jim gained a Licence in Dental Surgery at Sheffield University in 1955. After 8 months as a house officer in the dental hospital there he was called up for National Service and was posted to the Royal Army Dental Corps at Catterick. He returned with his wife, Kath, to his father's Norfolk practice in 1957 and was joined there, after his father's retirement, by his partner, Godfrey Dennis. They ran a mainly NHS general practice with a special interest in pain and apprehension control. He was a member of his Local Dental Committee from 1959 and was its secretary 1961-72, chairing the conference of LDCs in 1977. He was chairman of the Norfolk and Norwich Section in 1964 and had been a member of the Eastern Counties Branch council since 1963, serving as its assistant secretary 1969-74, secretary 1974-79, and Branch President in 1980. Latterly, he was a Vice-President of the Branch. He was first elected onto the Representative Board in 1970 and by the Board onto the General Dental Services Committee in 1971. He was elected to the Council of the Association in 1974 and to its Finance Sub-Committee in 1976. In March 1982 he was voted into office as Chairman of the Representative Board and served in that post for two years. In 1992, he was made a Fellow of the British Dental Association in recognition of his outstanding service, an accolade of which he was very proud.

Jim and Kath had three children, Tony, Claire and Chris. Sadly, Kath died in 1991. Jim married his second wife, Linda, in 1995. He was a member of Dereham Round Table and then Dereham Rotary Club. He retired from practice in 1993 and became a supporter of his village sports club, as well as taking up golf. Jim was a big man, in every sense, a gentle giant. He will be greatly missed, not only by his family, but also by his local community, of which he was such an active member.

Malcolm L. Heath

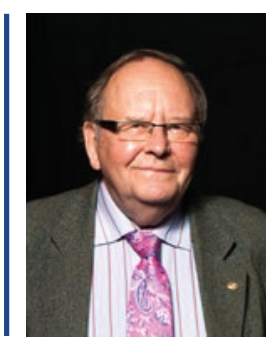

\section{Christopher John Rossiter Kettler MBE} 1939-2019

Chris Kettler's defining achievement was his contribution to the formation of the British Orthodontic Society, but he is remembered for so much more. A specialist practitioner, he was Secretary of the British Orthodontic Society (BOS) three times, he was also an active British Dental Association member, an expert witness for Dental Protection, and among many other voluntary roles, Secretary to the Bedfordbased Great Ouse Orthodontic Study group. He worked selflessly for orthodontics in innumerable ways.

His mastery of the Begg appliance was legendary and his ability to demonstrate it fondly remembered by colleagues he taught as a postgraduate clinical lecturer at the Eastman. He had the potential to become a consultant but he opted instead to open his own practice limited to orthodontics in Bedford. The new NHS orthodontic contract of April 2006 was based largely on the Bedfordshire Pilot evolved by Chris with Sue Gregory, although he always denied responsibility for the Unit of Orthodontic Activity! He was awarded the MBE in 2011 for services to orthodontics.

Chris was Secretary of the British Association of Orthodontists, and the British Society for the Study of Orthodontics, and the first Secretary of the newly formed BOS in 1994. Prior to this, he had the key role of Secretary of the unification working group, a committee of orthodontists set up to merge five orthodontic organisations into one. The formation of the BOS finally came about after 15 years of hard graft by Chris and colleagues.

Most specialist organisations are limited to specialists, but not the BOS. Chris passionately believed that everyone practising orthodontics should be part of the Society. He was equally determined to recognise the role of dental care professionals. He was instrumental in the establishment of the role of the Orthodontic Therapist (OT), serving on the GDC Working Group for the OT Curriculum. He served for a time as President of the Orthodontic National Group for Orthodontic Nurses and Therapists.

He was keen for the BOS to be influential in European affairs and for many years attended meetings of European societies. Latterly, he was an invaluable member of the BOS Archive and Museum Committee. Chris liked to avoid the limelight and work behind the scenes but his enormous contribution to the specialty ensures he rightly takes his place as a luminary in the history of UK orthodontics.

Ever proud of his family, he is survived by three sons and several grandchildren.

David Tidy 